\title{
WHAT ARE THE LEGAL MECHANISMS FOR SEEKING SOLUTIONS TO DISPARITIES IN THE DELIVERY OF CARE IN THE NHS AND WHERE DOES LIABILITY LIE?
}

\author{
Affifa Farrukh* \\ This fundamental principle: that we are all citizens, and \\ equal citizens, of one State. ${ }^{1}$
}

Muhammad Ali Jinnah

\begin{abstract}
This review deals with the potential role of Commissions and Inquiries into delivering a just service to patients from ethnic minorities. It takes as an example the experience of people with inflammatory bowel disease and the National Health Service in the United Kingdom. Although there are many legal safeguards, the avenues open to groups of patients who experience discrimination, are limited and generally ineffective. Government inspired responses such as Commissions and Inquiries are inadequate and not fit for purpose.
\end{abstract}

Key words: Discrimination, Healthcare, NHS, Commissions, Inquiries, Judicial Review

\section{INTRODUCTION}

Ethnic discrimination in delivery of health care is a worldwide problem. Wellknown examples include the notorious Tuskegee experiment where the US Public Health Service withheld appropriate treatment for syphilis from more than 600 African American share croppers between 1932 and 1972. ${ }^{2}$ However, the issue was and is much more widespread than the Deep South. In 1988 Kjellstrand demonstrated that non-White patients were half as likely to receive a kidney

\footnotetext{
* E-mail: farrukh_affi@yahoo.com

1 Muhammad Ali Jinnah's first Presidential Address to the Constituent Assembly of Pakistan (11 August 1947) para 7.

2 JH Jones, Bad Blood: The Tuskagee Syphilis Experiment (The Free Press 1992) 1.
} 


\section{WHAT ARE THE LEGAL MECHANISMS FOR SEEKING SOLUTIONS TO DISPARITIES IN THE DELIVERY OF CARE IN THE NHS}

transplant across the USA. ${ }^{3}$ Similarly, Black patients were twice as likely to go untreated for bladder cancer. ${ }^{4}$ By the end of the 20th century it was well recognised within the USA that Black patients were less likely than White patients with a comparable disease burden to undergo cardiac revascularisation, leading to lower survival rates. ${ }^{5}$ In 1998 Bhopal from Newcastle summarised the effect of discrimination on health care in the USA and drew attention to similar issues in the UK. ${ }^{6}$

\section{EXAMPLES OF DISCRIMINATION IN THE DELIVERY OF CARE IN THE UK}

In 1998 a study from Leicester had shown that South Asian patients admitted into coronary care units received poorer care than their European counterparts. ${ }^{7}$ Such differences in the nature of the support and treatment offered to patients from ethnic minorities in the UK continue to be reported. Black women with breast cancer were less likely to have surgery and more likely to be simply offered chemotherapy, whilst Pakistani women were less likely to be offered radiotherapy or hormone treatment than White women. ${ }^{8}$ In the UK in the 21st-century ethnic minority patients on the renal transplant register are still less likely to receive a donor organ than White patients. ${ }^{9}$ In the field of mental health, Black service users tend to be given injectable depot treatments rather than offered tablets or cognitive

3 CM Kjellstrand, 'Age, sex and race inequality in renal transplantation' (1988) 148 Archives of Internal Medicine 1305.

4 WJ Mayer and WP McWhorter, 'Black/White differences in non-treatment of bladder cancer patients and implications for survival' (1989) 79 American Journal of Public Health 772.

5 ED Peterson and others, 'Racial variation in the use of coronary - revascularization procedures. Are the differences real? Do they matter?' (1997) 336 New England Journal of Medicine 480.

${ }^{6} \mathrm{R}$ Bhopal, 'Spectre of race and racism in health and health care: lessons from history and the United States' (1988) 316 British Medical Journal 1970.

7 JT Lear and others, 'Myocardial infarction and thrombolysis: a comparison of the Indian and European populations on a coronary care unit' (1994) 28 Journal of the Royal College of Physicians (London) 143.

8 RH Jack, EA Davies and H Møller, 'Breast cancer incidence, stage, treatment and survival in ethnic groups in South East England' (2009) 100 British Journal of Cancer 545.

9 U Udavaraj and others, 'UK Renal Registry 16th annual report: chapter 6 demographics and outcomes of patients from different ethnic groups on renal replacement therapy in the UK’ (2013) 125 Nephron Clinical Practice 111. 
behavioural therapy. ${ }^{10}$ Although such differences are not policy driven it seems unlikely that they are due to overt racism. In a study of nine NHS trusts with significant South Asian populations only three were significantly less likely to provide expensive biologic therapy for South Asian patients with Crohn's disease. ${ }^{11}$ In one of these trusts, a separate study found that South Asian patients with ulcerative colitis experienced sub-standard care over a 10-year period when compared to White British patients. ${ }^{12}$ This included being seen less often by consultants, less frequent investigations and being discharged more frequently. There was no evidence that they had milder disease as they needed surgery as often as White British patients.

National Health Service (NHS) workers have shown patients various forms of discrimination. For example, a qualitative study of 30 registered nurses working in hospitals in Leeds identified racism affecting their practice in their care of Pakistani patients. ${ }^{13}$ Earlier a small group of South Asian inpatients had described how they felt that they needed to fit into what they described as an 'English place'. ${ }^{14}$ In Middlesbrough, only 5 per cent of Pakistani patients were told of the availability of professional translators to help with consultations. ${ }^{15}$ Problems with effective communication between district nurses and South Asian patients meant compliance with treatment regimes was not fully understood and assessments of patients' ongoing needs were inaccurate. ${ }^{16}$ NHS England recognised the importance of this issue in a policy statement directed at ensuring that a high quality interpreting and

10 J Das-Munshi, D Bhugra and MJ Crawford, 'Ethnic minority inequalities in access to treatments for schizophrenia and schizoaffective disorders: findings from a nationally representative cross-sectional study' (2018) 16 BMC Medicine 55.

11 A Farrukh and JF Mayberry, 'Ethnic variations in the provision of biologic therapy for Crohn's disease: a Freedom of Information study’ (2015) 83 MedicoLegal Journal 104.

12 A Farrukh and J Mayberry, 'Patients with ulcerative colitis from diverse populations: the Leicester experience' (2016) 84 MedicoLegal Journal 31.

13 JD Cortis, 'Meeting the needs of minority ethnic patients' (2004) 48 Journal of Advanced Nursing 51.

${ }^{14} \mathrm{~V}$ Vydelingum, 'South Asian patients' lived experience of acute care in an English hospital: a phenomenological study' (2000) 32 Journal of Advanced Nursing 100.

15 R Madhok, A Hameed and R Bhopal, 'Satisfaction with health services among the Pakistani population in Middlesborough, England' (1998) 20 Journal of Public Health Medicine 295.

$16 \mathrm{~K}$ Gerrish, 'The nature and effect of communication difficulties arising from interactions between district nurses and South Asian patients and their carers' (2001) 33 Journal of Advanced Nursing 566. 


\section{WHAT ARE THE LEGAL MECHANISMS FOR SEEKING SOLUTIONS TO DISPARITIES IN THE DELIVERY OF CARE IN THE NHS}

translation service was available. ${ }^{17}$ Unfortunately the Care Quality Commission has shown this is often not readily available with hospitals making use of limited telephone translation services and non-professional staff. ${ }^{18}$

\section{THE NATURE OF THE EVIDENCE AND POTENTIAL RESPONSES}

Over the last 20 years a substantial body of evidence has demonstrated that there is significant discrimination in the way health care is accessed and delivered by the NHS. This discrimination has an ethnic basis and can have a direct impact on morbidity and mortality. The studies have been conducted on cohorts of patients and used epidemiological techniques. Individual cases have not been reported in the medical literature and when, and if, litigation has been contemplated it is likely such cases were settled prior to any trial on a no admission of liability basis and have included clauses about confidentiality. However, there is also evidence that discrimination based on ethnicity is not universal and so provides hope that appropriate interventions, including legal ones, might change such behaviour patterns. Indeed Sir William MacPherson summarised the situation by suggesting:

It is incumbent on every institution to examine their policies and the outcomes of their policies and practices to guard against disadvantaging any section of our communities... There must be an unequivocal acceptance of institutional racism and its nature before it can be addressed. ${ }^{19}$

This review will investigate the potential role of judicial processes in dealing with discrimination in the delivery of care, as education, non-legal interventions and published research alone have failed. The routes to obtaining a more just delivery of care will be considered and patients with inflammatory bowel disease will act as a model. However, the observations will apply across the board and in

17 NHS England, 'Principles for high quality interpreting and translation services (Version 1.19)' <www.england.nhs.uk/commissioning/wp-content/uploads/sites/12/2015/ 03/it_principles.pdf $>$ accessed 4 November 2018.

18 Care Quality Commission, University Hospitals of Leicester NHS Trust Quality Report (2014) <www.cqc.org.uk/sites/default/files/new_reports/AAAA0708.pdf> accessed 4 November 2018.

19 Home Office, The Stephen Lawrence Inquiry (Cm4262-1, 1999) 109 </assets. publishing.service.gov.uk/government/uploads/system/uploads/attachment_data/ file/277111/4262.pdf> accessed 7 May 2020. 
some areas all groups will be considered together. The major approaches that will be discussed will be Royal Commissions, Inquiries and Judicial Review.

\section{POTENTIAL LEGAL APPROACHES TO THE ISSUE OF DISCRIMINATION IN DELIVERY OF CARE TO BLACK AND ETHNIC MINORITIES}

The information available on discrimination in delivery of care to Black and Ethnic Minorities (BEM) is almost exclusively based on qualitative social research and quantitative epidemiological studies. There is no evidence publicly available of individuals who have sued in tort or contract where breach of duty has been linked to racism in the UK. To some degree this contrasts with the situation in the USA where at a press conference called by the Medical Committee for Human Rights, Dr Martin Luther King said: "Of all the forms of inequality, injustice in health is the most shocking and the most inhuman because it often results in physical death." 20 He went on to accuse the American Medical Association of a "conspiracy of inaction" with a call for court action against doctors to enforce the Civil Rights Act. ${ }^{21}$

\section{ETHNIC DISCRIMINATION IN HEALTH IN UK}

In 1987 the Commission for Racial Equality found that 40 per cent of white doctors and 50 per cent of BEM doctors working across England believed there was discrimination in the NHS which affected people's health. ${ }^{22}$ Subsequently Ahmad et al. reported that general practitioners held negative attitudes about Asian patients, considering them to require more time and be less compliant. ${ }^{23}$

The issues in question are what approaches might be taken to change the situation for the BEM population as a whole and how should individuals who have experienced poor care and suffered injury - the classic breach of duty and causation scenario - be best advised.

20 Associated Press, 'King berates medical care given negroes' Oshkosh Daily Northwestern (Oshkosh, Wisconsin, 26 March 1966) <www.hcdi.com/2018/01/12/ dr-martin-luther-king-on-health-care-injustice> accessed 7 May 2020.

21 J Hoberman, Black and Blue. The Origins and Consequences of Medical Racism (University of California Press 2012) 27.

${ }^{22}$ L Kushnick, 'Racism, the National Health Service, and the health of Black people' (1988) 18 International Journal of Health Service 457.

23 WIU Ahmad, M Baker and E Kernohan, 'General practitioners perceptions of Asian and non-Asian patients’ (1991) 8 Family Practice - An International Journal 52. 


\section{WHAT ARE THE LEGAL MECHANISMS FOR SEEKING SOLUTIONS TO DISPARITIES IN THE DELIVERY OF CARE IN THE NHS}

\section{HOW TO DEAL WITH POOR CARE FOR THE BEM POPULATION}

The issue of poor care due to ethnicity is unacceptable nationally and so should be dealt with at that level. Indeed, as most data relate to qualitative or large population studies, such an approach may be the only effective way in which any progress can be made.

The three main routes which might be followed are: a Royal Commission, a Public Inquiry or a Judicial Review.

\section{Royal Commissions}

Royal Commissions are set up by government in the name of the Crown to advise in a non-partisan way on controversial issues of national importance. They are usually concerned with broad policy issues and generally take between two and four years to deliver a report. They have dealt with health issues, but their use has declined over the last 30 years. An example of such a commission was in the longterm care of the elderly. ${ }^{24}$ However, its effectiveness was limited by a dissentient note of two members who considered the proposals financially unrealistic and its main recommendation was rejected by the government. ${ }^{25}$

\section{Public Inquiries}

During the last 20 years Public Inquiries have become significant tools for investigation of accountability. In healthcare this has included the BSE and the Shipman Inquiries. ${ }^{26}$ Beer has argued their purpose is to identify precisely what happened,

\footnotetext{
${ }^{24}$ S Sutherland, Royal Commission on Long Term Care. With Respect to Old Age (Stationery Office 1999) 1.

${ }^{25}$ R Stout, 'Response to Royal Commission on long term care' (2000) British Medical Journal $315<$ bmj.com/rapid-response/2011/10/28/response-royal-commission-long-termcare> accessed 7 May 2020.

${ }^{26}$ L Phillips, The BSE Inquiry (The Stationery Office 2000) 1 <webarchive. nationalarchives.gov.uk/20060802142310/http://www.bseinquiry.gov.uk $>$ accessed 7 May 2020; J Smith The Shipman Inquiry (The Stationery Office 2005) $1<$ https://www.pslhub. org/learn/investigations-risk-management-and-legal-issues/investigations-andcomplaints/investigation-reports/other-reports-and-enquiries/the-shipman-inquiry-20022005-r867/> accessed 7 May 2020.
} 


\section{THE DENNING LAW JOURNAL}

decide why it happened and who was to blame and also to identify what can be done to prevent it happening again. ${ }^{27}$

All statutory inquiries are now regulated by the Inquiries Act 2005. In s 2(1) it limits the remit of an Inquiry so it may not "rule on, and has no power to determine, any person's civil or criminal liability". However, in s 2(2) it states "an inquiry panel is not to be inhibited in the discharge of its functions by any likelihood of liability being inferred from facts that it determines or recommendations that it makes".

The public have greatest trust in Inquiries chaired by doctors and nurses. ${ }^{28}$ However, in any Inquiry into why patients from ethnic minorities receive poorer quality care, members of these two professional groups would have an obvious conflict of interest. An example where a Public Inquiry into health service issues was chaired by someone without a healthcare background was that led by Professor Kennedy into paediatric cardiac surgery at Bristol Royal Infirmary. ${ }^{29}$ Its probing nature had a significant impact on health care in the UK. It identified a "club culture" amongst surgeons with a lack of insight into their clinical failings. ${ }^{30}$ This situation is all too reminiscent of the care experienced by BEM patients. As a direct result of the inquiry some 16 years later NHS England set as its objectives:

Securing the best outcomes for all .....

Tackling variation ....

Improving patient experience. ${ }^{31}$

Unfortunately, this standard was only for paediatric cardiac surgery services.

27 J Beer, 'Introduction' in J Beer, J Dingemans and R Lissack, Public Inquiries (OUP 2011) 1 .

28 Institute for Government, 'General trust in the professions of individuals who have chaired public inquiries since 1990' (2017) <instituteforgovernment.org.uk/charts/generaltrust-professions-individuals-who-have-chaired-public-inquiries-1990 $>$ accessed 7 May 2020.

29 Department of Health, Learning from Bristol: the report of the public inquiry into children's heart surgery at the Bristol Royal Infirmary 1984-1995 (Cm 5207 - 1, 2001) 1.

${ }^{30}$ C Dyer, 'Bristol Inquiry condemns hospital's "club culture", (2001) 323 British Medical Journal 181.

31 NHS England, 'Action to implement recommended standards nationally to be announced next week' (2016) <england.nhs.uk/2016/06/childrens-heart-surgery-standards/> accessed 7 May 2020. 


\section{WHAT ARE THE LEGAL MECHANISMS FOR SEEKING SOLUTIONS TO DISPARITIES IN THE DELIVERY OF CARE IN THE NHS}

\section{Judicial Review}

Lord Donaldson MR in $R v$ Lancashire County Council ex $p$. Huddleston described the role of judicial review in the 21st century as "a new relationship between the courts and those who derive their authority from public law, one of partnership based on a common aim, namely the maintenance of the highest standards of public administration". ${ }^{32}$ There is a contractual duty of candour imposed on all providers of services to NHS patients in the UK to give them all necessary support and relevant information in the event of a reportable patient safety incident, which could have or did result in moderate or severe harm or death. The fact that the duty exists where harm "could" have been caused would suggest that once clinicians become aware their unit is delivering sub-standard care, they are under a professional, and probably legal, obligation to inform BEM patients individually. Such patients would need to be told their care will be comparable to that of an English patient if they go to a different NHS Trust which serves all communities equally. In individual cases, any sub-standard care with adverse consequences would be actionable, under the tort of negligence.

Of course, such racist attitudes should have been dealt with by the Trust's management as it contravenes the first "right" under the NHS Constitution:

The NHS provides a comprehensive service, available to all irrespective of gender, race, disability, age, sexual orientation, religion, belief, gender reassignment, pregnancy and maternity or marital or civil partnership status. The service is designed to improve, prevent, diagnose and treat both physical and mental health problems with equal regard. It has a duty to each and every individual that it serves and must respect their human rights. At the same time, it has a wider social duty to promote equality through the services it provides and to pay particular attention to groups or sections of society where improvements in health and life expectancy are not keeping pace with the rest of the population (Italics added for emphasis). ${ }^{33}$

The abuse experienced by elderly patients at Stafford Hospital led to a Public Inquiry and successful claims against Mid Staffordshire NHS Foundation Trust based on wilful negligence and contravention of Articles 2, 3 and 8 of the Human Rights Act (1998). Nevertheless, it is more likely individuals who have experienced poor care and suffered damage will continue to seek compensation through the

32 [1986] 2 All ER 941.

${ }^{33}$ Department of Health, The NHS Constitution - The NHS belongs to us all (Williams Lea 2015) 2. 
traditional route of medical negligence claims. However, judicial review has a clear role to play in deciding whether a public body has made its decisions in an arbitrary or thoughtless way. The traditional purpose of judicial review has been to examine the legality of decisions made by government or by its agents. A victory by a claimant can have various outcomes, but in relation to discrimination an NHS trust could be required to change its policies so as to eliminate inequitable care.

\section{HOW TO DEAL WITH POOR CARE FOR INDIVIDUALS FROM THE BEM POPULATION}

Poor care for patients from the BEM population is both a breach of duty of care and of professional duty. The General Medical Council's (GMC) equivalent of a Core Duty in Good Medical Practice at Domain 4 s59 states:

You must not unfairly discriminate against patients or colleagues by allowing your personal views to affect your professional relationships or the treatment you provide or arrange. You should challenge colleagues if their behaviour does not comply with this guidance. ${ }^{34}$

The guidance clarifies that it includes: "your views about a patient's or colleagues lifestyle, culture or their social or economic status, as well as the characteristics protected by legislation" ${ }^{35}$ The GMC enlarges on the consequences of a doctor's personal beliefs and attitudes and states he or she must not: "treat patients unfairly, ... deny patients access to appropriate medical treatment or services, .... not cause patients distress". ${ }^{36}$ Although this latter guidance largely relates to situations where doctors have a conscientious objection to providing certain procedures, such as termination of pregnancy and male circumcision, it is also directly relevant to work in a Trust which underserves members of the BEM community. Failure to inform patients that a Trust has been underserving the BEM could form grounds for referral to a Fitness to Practice Committee. If the complaint

\footnotetext{
${ }^{34}$ General Medical Council, Good Medical Practice <gmc-uk.org/ethical-guidance/ ethical-guidance-for-doctors/good-medical-practice/domain-4---maintainingtrust\#paragraph-59> accessed 7 May 2020.

35 ibid.

36 General Medical Council, Personal Beliefs and Medical Practice 4 <gmc-uk.org/ ethical-guidance/ethical-guidance-for-doctors/personal-beliefs-and-medical-practice/ personal-beliefs-and-medical-practice> accessed 7 May 2020.
} 


\section{WHAT ARE THE LEGAL MECHANISMS FOR SEEKING SOLUTIONS TO DISPARITIES IN THE DELIVERY OF CARE IN THE NHS}

is upheld by the Medical Practitioners Tribunal this could lead to either suspension or permanent erasure of that doctor from the medical register. ${ }^{37}$

However, none of these actions will compensate a patient or family members for poor treatment which has caused harm. The most effective route for seeking financial redress in such a situation remains through the tort of negligence. In this case the issue of why a patient received sub-standard treatment is of limited importance, rather it is whether they received such treatment and how it compares with that provided by a competent practitioner.

\section{ROYAL COMMISSION FOR INVESTIGATION OF BEM HEALTHCARE}

In 1085 William the Conqueror instituted the first Royal Commission when he sent commissioners throughout the country to collect data which would constitute the Domesday Book. Its purpose was to record property holdings and this concept of investigating and reporting on a specific matter remains the essence of Royal Commissions, although they now lack the enforcement powers which William gave to his commissioners.

In the UK the executive initiates Commissions through powers delegated to it by the Crown. Starr has pointed out that most recent Royal Commissions have been concerned with broad policy rather than specific issues requiring timely actions. ${ }^{38}$ As a result there has been only one recent example dealing with health issues. This was the Royal Commission on the National Health Service, which commenced work in 1976 and delivered its report three years later. Its terms of reference were to consider "the best use and management of financial and manpower resources of the National Health Service". ${ }^{39}$ What remains unclear is "why, on some occasions, are the recommendations of advisory bodies accepted and implemented with alacrity while at other times they are side-lined, buried or wilfully ignored?" ${ }^{40}$ Owens went on further to suggest that "the authority of the

\footnotetext{
37 General Medical Council, Fitness to Practice Procedures <whatdotheyknow.com/ request/223973/response/564046/attach/html/3/Apok\%206512\%20response.pdf.html> accessed 7 May 2020.

${ }^{38}$ G Starr, 'Public inquiries in the United Kingdom' in S Prasser and H Tracey (eds), Royal Commissions \& Public Inquiries: Practice \& Potential (Connor Court Publishing Pty Ltd 2014) para 3.01.

39 A Merrison, Royal Commission on the National Health Service: Report (HMSO 1979) 1.

40 S Owens, 'Experts and the Environment: The UK Royal Commission on Environmental Pollution 1970-2011' (2012) 24 Journal of Environmental Law 1.
} 
advice and its interplay with interests, institutions and power" were important factors, but with time these tended to diminish.

\section{Royal Commissions and Health Issues}

Despite such apparent restrictions, the Royal Commission on the National Health Service took a wide view of its remit and considered its work must be informed by the notion that the NHS was "a service to patients". ${ }^{41}$ Almost 40 years later, observations made in the report continue to be relevant and this emphasises the potential long-term value of Royal Commissions. For example, it took the view that it should: "have some comments on the way NHS priorities are determined. First, we believe it is important that the lay public should be involved in the process". ${ }^{4}$

However, the BEM community were viewed as contributing to the difficulties of the NHS rather than being a group who were underserved. These views were reflected in the following extracts:

7.53 Some of these symptoms are due to economic decline and the accompanying poverty and social problems, but others may arise from the high cost of accommodation or the special demands of an aged, migrant or homeless population. ${ }^{43}$

7.61 The special needs of patients who come from ethnic minorities require sensitive handling by the NHS. The evidence we took from their representatives suggests that many NHS workers are not aware of cultural, language, literacy and dietary problems which may affect these groups. ${ }^{44}$

Although the issues of the BEM community only figured in a relatively small way in this report, during recent years they have come more to the fore. The question, however, is whether they would be considered sufficiently broad and of such importance as to warrant a Royal Commission investigating the issue over a period of years and at considerable expense.

The Royal Commission on the NHS was initiated under a Labour government, but its report was published when Margaret Thatcher was Prime Minister and most of its recommendations were not implemented. This underlines the major weakness of Commissions which is that their recommendations lack legal force.

\footnotetext{
41 ibid para 1.1.

42 ibid para 6.7.

43 ibid para 7.53 .

44 ibid para 7.61 .
} 


\section{WHAT ARE THE LEGAL MECHANISMS FOR SEEKING SOLUTIONS TO DISPARITIES IN THE DELIVERY OF CARE IN THE NHS}

However, recently Saatchi (2017) has suggested that there is a growing appetite for the appointment of a Royal Commission to sort out the current problems of the NHS:

As a constitutional mechanism, a Royal Commission is uniquely placed to draw attention to some of the enormous, long-term challenges that many members of the public, and Westminster, are not fully aware of. A Commission's investigatory powers, and capacity to provide evidenced-based review free from the constraints of the immediate political cycle, allow it to craft solutions that command the support of practitioners and politicians alike. When set up properly, its recommendations carry a unique legitimacy that could be essential to securing a lasting, bipartisan settlement on the NHS. ${ }^{45}$

Within the issues Saatchi considered most pressing was that of underserved BEM communities within the UK. If he is correct that there is a bipartisan wish within Parliament to see a Royal Commission to deal with these issues then it could become a reality.

\section{Mechanisms for a Royal Commission}

Royal Commissions are created by a formal Order in Council and confirmed with the Great Seal. ${ }^{46}$ Subsequently an advertisement is placed by the Privy Council in The Gazette which can: "specify the leader of the commission to be appointed, or an invitation to submit evidence to the inquiry or other matters pertaining to royal commissions" ${ }^{47}$ Its membership will generally be selected incrementally and eclectically from amongst experts and lay people. ${ }^{48}$ Clearly the composition of any Royal Commission concerned with discrimination in the delivery of health care would be critical and need to represent those whom the NHS is meant to serve.

Royal Commissions lack statutory power to compel witnesses to attend and for documents to be disclosed, but their strength lies in the formality of the

45 M Saatchi, An NHS Royal Commission. From Fighting Fires to Lasting Settlements (Centre for Policy Studies 2017) 14.

46 TJ Lockwood, 'A History of Royal Commissions' (1967) 5 Osgoode Hall Law Journal 172 .

47 'Appointment of Royal Commissions (1112)' <www.thegazette.co.uk/all-notices/ content/121> accessed 7 May 2015.

48 PA Thomas, 'Royal commissions' (1982) 3 Statute Law Review 40. 
proceedings and the prestige of being conducted under a royal warrant. ${ }^{49}$ Although the median time to produce a report is between two and four years, at least a dozen commissions have done so more rapidly, ${ }^{50}$ although time would not be a factor in this case.

\section{Public Inquiries and BEM Healthcare}

Howe (1999) described the purpose of inquiries as being to provide "a full and fair account of what happened especially in circumstances where the facts are disputed, or the course and causation of events is not clear". ${ }^{51}$ This is directly relevant to discrimination in delivery of care to BEM communities which Trusts and individual doctors dispute and its cause is unclear. A more cynical interpretation of their role has been put forward by Habermas who considers their purpose is to re-establish and justify state authority, and thus to maintain 'the requisite level of mass loyalty ${ }^{52}$ In similar vein, Brown believes such "public discourse depoliticizes disaster events, legitimates social institutions, and lessens anxieties by concocting myths that emphasize our omnipotence and capacity to control". ${ }^{53}$

In 2005 the Inquiries Act established statutory inquiries and in 2006 the Inquiry Rules were published. Non-statutory inquiries continue, however, and are still used by a variety of organisations including the NHS. The choice as to which of these two forms an inquiry will take often appears quite arbitrary.

\section{STATUTORY PUBLIC INQUIRIES}

The Inquiries Act 2005 enables a Minister to create an inquiry:

1 (1) ..... where it appears to him that

(a) particular events have caused, or are capable of causing, public concern

49 AW Bradley and KD Ewing, Constitutional and Administrative Law (13th edn, Longman 2003) 305; JS Caird, 'Public Inquiries: non-statutory commissions of inquiry' (2016) 02599 House of Commons Library Briefing Paper 20.

50 P Barlow, 'The lost world of royal commissions' (2013) <instituteforgovernment.org. uk/blog/lost-world-royal-commissions $>$ accessed 7 May 2020.

51 G Howe, 'The management of public inquiries' (2002) 70 The Political Quarterly 295.

52 J Habermas, Legitimation crisis (Beacon Press 1973) 46.

53 A Brown, 'Authoritative Sensemaking in a Public Inquiry Report' (2003) 25 Organization Studies 952. 


\section{WHAT ARE THE LEGAL MECHANISMS FOR SEEKING SOLUTIONS TO DISPARITIES IN THE DELIVERY OF CARE IN THE NHS}

The chairman, its membership and final terms of reference are determined by the minister. He must inform Parliament of his actions, but does not require its permission or approval. Therefore, such Inquiries are under the control of the Executive. Hence their role in investigation of discrimination in the delivery of care by the NHS might be undermined. However, there is some hope. In 2018, an independent public statutory inquiry into the use of infected blood was set up. Its terms of reference are:

To examine the circumstances in which men, women and children treated by National Health Services in the United Kingdom (collectively, the "NHS") were given infected blood and infected blood products, in particular since 1970. ${ }^{54}$

Clearly the role of the NHS will be investigated, but it must be remembered it has taken almost 50 years to arrive at this point, and this included the non-statutory Archer Inquiry in $2009 .{ }^{55}$ This inquiry was funded privately by individuals, the Southern Building Company and the Professional Footballers Association. ${ }^{56}$ Its fate is a salutary lesson as it went offline and became difficult to access. As Whyte (2010) has pointed out even a statutory inquiry "is a legally sanctioned forum that has no power of legal sanction". ${ }^{57}$

\section{Statutory Inquiries and Health Issues}

However, statutory inquiries can limit the information which they publish under s 25 when there is:

(5) (b) any risk of harm or damage that could be avoided or reduced by withholding any material;

(c) any conditions as to confidentiality subject to which a person acquired information that he has given to the inquiry.

(6) In subsection (5)(b) "harm or damage" includes in particular(a) death or injury ${ }^{58}$

\footnotetext{
$54<$ infectedbloodinquiry.org.uk/sites/default/files/Terms-of-Reference-Infected-BloodInquiry.pdf $>$ accessed 7 May 2020.

55 Independent Public Inquiry: Contaminated Blood \& Blood Products < archercbbp.com/ public > accessed 7 May 2020.

56 Archer Report 2009 <factor8scandal.uk/archer-report-2009> accessed 7 May 2020.

57 D Whyte, 'Don't Mention the Motive for War' (2010) 82 Criminal Justice Matters 8.

58 The Inquiries Act 2005.
} 


\section{THE DENNING LAW JOURNAL}

All medical information is confidential and many patients would feel that they had suffered further harm on discovering that they had received less appropriate care than other UK citizens.

A further major limitation of statutory inquiries is that: "2 (1) An inquiry panel is not to rule on, and has no power to determine, any person's civil or criminal liability".59 This has significant implications for recipients of infected blood and would have similar consequences for any inquiry into discrimination in delivery of healthcare.

Under s 19 of the Act restrictions can be imposed by a minister on disclosure or publication of evidence provided to the inquiry as well as limiting public attendance. Public acknowledgement of discrimination in delivery of care might be seen by the Executive as a matter which would not allay public concerns and so lead to suppression of any relevant evidence or its publication. For such reasons, many judges, such as Saville L, would decline to chair inquiries held under the Act. ${ }^{60}$ To some degree this may explain the limited number of inquiries held under the Act and the continuing popularity of non-statutory inquiries. In addition, Elliott has drawn attention to the belief that when a judge does chair an inquiry into matters of public concern there will be greater accountability and clearer evidence of independence from the Executive. ${ }^{61}$ Clearly, when a minister controls the processes of an inquiry these beliefs would be seriously undermined.

Other statutory inquiries related to health have included the Cdiff Inquiry, the Vale of Leven Inquiry, the Penrose Inquiry on infected blood in Scotland and the Mid Staffordshire NHS Foundation Trust Inquiry. ${ }^{62}$ The Cdiff Inquiry was chaired by the Chief Medical Officer for Wales and its three other members were all from medical backgrounds. It was concerned with an outbreak of Clostridium difficile induced diarrhoea in hospitals in Northern Ireland and was linked to 31 deaths. The report is no longer readily available. In contrast the Vale of Leven Inquiry which was chaired by a retired judge, MacLean L, is still available. It too concerned the death of 34 patients from Clostridium difficile and was set up by the Scottish government in response to public pressure. The same is also true for the Penrose Inquiry into Hepatitis C/HIV infection acquired from infected blood supplies in Scotland, where the chairman was a Scottish Court of Session judge.

\footnotetext{
59 The Inquiries Act 2005.

60 Beer (n 27) 25.

61 M Ellliott, 'Should judges lead public inquiries?' (2014) <publiclawforeveryone. com/2014/07/10/should-judges-lead-public-inquiries> accessed 7 May 2020.

62 G Cowie and M Sandford, 'Statutory Commissions of Inquiry: the Inquiries Act 2005' (2018) SN06410 House of Commons Library Briefing Paper 32.
} 


\section{WHAT ARE THE LEGAL MECHANISMS FOR SEEKING SOLUTIONS TO DISPARITIES IN THE DELIVERY OF CARE IN THE NHS}

\section{Statutory Inquiries and Public Pressure}

In the case of the Vale of Leven Inquiry pressure came from families of those who had died in the Clostridium difficile outbreaks, as well as senior members of the medical profession for a public statutory inquiry. However, the turning point was an exchange between Nicola Sturgeon, who was Cabinet Secretary for Health and Wellbeing, whilst standing in for the First Minister, and Iain Gray at First Minister's Question Time:

The families of those who died want a public inquiry now. Britain's leading epidemiologist wants a public inquiry now. This Parliament voted for a public inquiry in September. Ms Sturgeon has admitted today that there is no reason why that cannot happen. She herself is the only obstacle. How many people need to tell her that she is wrong before she calls a public inquiry? ${ }^{63}$

Although the report was robust in its criticisms, interested parties still accused it of being an example of the NHS investigating itself. ${ }^{64}$ Nevertheless, it specifically stated: "Scottish Ministers bear ultimate responsibility for NHS Scotland and even at the level of the Scottish Government the systems were simply not adequate."65

\section{Statutory Inquiries and Politics}

In 2004 Sir Robert Francis, a barrister with significant experience of chairing inquiries, submitted a Memorandum to the Public Administration Select Committee which was deliberating on the Inquiries Act, in which he suggested that the benefits of public inquiries "must be weighed against the burdens that inquiries of any public nature place on those who are party to them, and the public in general". 66 Amongst the burdens he identified were the anguish of victims, the workload placed on public bodies and the impact on staff under investigation, as well as cost. He went on to chair a non-statutory inquiry into the Mid Staffordshire Foundation Trust and was subsequently appointed by the Labour government to chair a

63 First Minister's Question Time Meeting of the Parliament 20 November 2008, session 3, col 2168.

64 S Carrell, 'Inquiry blames hospital for Cdiff deaths' <theguardian.com/society/2008/ aug/08/mrsa.nhs> accessed 7 May 2020.

65 L MacLean, The Vale of Leven Hospital Inquiry Report (APS Group 2014) 412.

66 R Francis, 'Memorandum by Robert Francis QC' (GBI 06) in House of Commons Public Administration Select Committee, Government Inquiry. Written Evidence (The Stationery Office Ltd 2004). 
more wide-ranging non-statutory inquiry into what had gone wrong at the Trust. However, Andrew Lansley, as Secretary of State for Health in the Coalition Government, decided it should be a statutory public inquiry. He gave as his reasons:

This was a failure of the trust first and foremost, but it was also a national failure of the regulatory and supervisory system, which should have secured the quality and safety of patient care. Why did it have to take a determined group of families to expose those failings and campaign tirelessly for answers? ${ }^{67}$

However, the decision was probably political. Indeed there is considerable evidence to suggest that Public Inquiries usually have political motives behind them, whether in response to growing public clamour or, as was suggested by Marr about the Scott Inquiry set up by John Major: "The administration was so lacking in authority that it was protecting itself, for the time being, with the borrowed authority of Lord Justice Scott. The tougher the judge, the stronger the shield." 68 Significant support for such a view comes from the experimental work of Sulitzeanu-Kenan on a web-based study of 474 UK citizens. ${ }^{69}$ Apart from blame avoidance the breathing space resulting from the inquiry process allows the significance of the event to move down the public agenda and so potentially limit the need for any active interventions. Against such a background Black and Mays have drawn attention to the formal absence of any method of assessing the impact of inquiries compared to their cost,$^{70}$ in other words whether they represent "value for money".

\section{Statutory Inquiries and the BEM Community}

Pressure groups, such as Cure the NHS, Tainted Blood and Factor 8, have been instrumental in bringing long-term pressure on governments to launch public inquiries into health issues. In the case of underserved ethnic minority groups a

67 HC Deb 9 June 2010, vol 511, col 333.

68 A Marr, 'Behold the backlash, sabres drawn' The Independent (8 June 1995) $<$ independent.co.uk/voices/behold-the-backlash-sabres-drawn-1585410.html> accessed 7 May 2020.

69 R Sulitzeanu-Kenan, 'If they get it right: an experimental test of effects of the appointment and reports of UK public inquiries' (2006) 84 Public Administration 623.

$70 \mathrm{~N}$ Black and N Mays, 'Public inquiries into health care in the UK: a sound basis for policy- making?’ (2013) 18 Journal of Health Service Research \& Policy 129. 


\section{WHAT ARE THE LEGAL MECHANISMS FOR SEEKING SOLUTIONS TO DISPARITIES IN THE DELIVERY OF CARE IN THE NHS}

public inquiry will only be achieved through persistent, targeted and informed tactics. Recruitment of politicians and public figures as influential supporters is central to a successful approach.

The question then arises as to how likely it is that patients with disparate diseases from a range of minority communities could come together and develop such a strategy. Interestingly inquiries related to health issues have usually concerned one group of patients, such as haemophiliacs, or those infected by Clostridium difficile. In the case of infected blood products it affected thousands of people, whereas the two inquiries concerned with deaths from Clostridium difficile involved less than 70 patients.

Assuming that a substantial pressure group developed amongst BEM patients and the executive considered the issue of sufficient consequence to set up an inquiry what would be important aspects? Clearly chairmanship of the inquiry and its membership would be critical. The chair would ideally be a judge and membership should include those with legal, cultural and epidemiology backgrounds. Although choice of membership lies with the minister, it is the chairman, with advice from the inquiry solicitor and counsel, who designates core participants. ${ }^{71}$

\section{Statutory Inquiries, the BEM Community and Core Participants}

Core participants are defined in s 5(2) of The Inquiry Rules 2006 as:

a. the person played, or may have played, a direct and significant role in relation to the matters to which the inquiry relates;

b. the person has a significant interest in an important aspect of the matters to which the inquiry relates; or

c. the person may be subject to explicit or significant criticism during the inquiry proceedings or in the report, or in any interim report.

BEM patients would come under s 5(2)(b), whilst (a) and (c) would include such Trusts as Pennine Acute Hospitals NHS Trust, Barking, Havering \& Redbridge University Hospitals NHS Trust and University Hospitals of Leicester NHS Trust. These three Trusts have underserved patients from the South Asian community who had inflammatory bowel disease..$^{72}$ In practice, core participants are often

71 P Skelton, 'The administration of an inquiry' in J Beer, J Dingemans and R Lissack (eds), Public Inquiries (OUP 2011) 156.

72 Farrukh and Mayberry, 'Ethnic variations in the provision of biologic therapy for Crohn's disease: a Freedom of Information study' (n 11). 
organisations representative of individuals rather than individuals, themselves. In the case of patients this could present an additional hurdle related to medical confidentiality and s 5(1) specifies that a person can only be designated as a core participant: "provided that person consents to being so designated".

The advantages of being a core participant have been summed up by Sir Brian Langstaff, chair of the Infected Blood Inquiry. The inquiry will:

engage with core participants on matters of practice and procedure which they will help to shape, and indeed will expect core participants to further the working of the Inquiry on an ongoing basis in ways that go beyond what it will ask of those who are not. ${ }^{73}$

Such views contrast with the status of infected patients who will simply "add to the Inquiry's store of knowledge". ${ }^{74}$ Core participants will be able to:

c. suggest lines of questioning (normally through their recognised legal representatives) to be pursued by Counsel to the Inquiry;

d. apply through their recognised legal representatives to the Chair to ask questions of witnesses during a hearing;

e. have access to the expert groups (through the Inquiry Secretariat) and be able to propose experts to be added to those groups;

f. be provided, prior to publication, with a copy of the report (or any interim report) which is to be published. ${ }^{75}$

Langstaff is clear about the importance of the term "significant" in s 5 (2) of The Inquiry Rules 2006. As other chairs of statutory public inquiries, Langstaff will decide who can have Core Participant status. Such a role will inevitably help shape the proceedings and outcome of any inquiry. Clearly, in any inquiry into underserving the BEM community the role of individual patient claimants will be limited. At best they will add to the narrative. The suggestion that organisations such as the Equality and Human Rights Commission will be able to act as Core Participants and speak on their behalf is undermined by its limited involvement with healthcare and unequal treatment related to protected characteristics. One of

73 B Langstaff, 'Chair's statement of Intent on Care Participant Status' (2018) $<$ infectedbloodinquiry.org.uk/sites/default/files/documents/Chairs-Statement-of-Intenton-Core-Participant-Status-1.pdf $>$ accessed 7 May 2020.

$74<$ infectedbloodinquiry.org.uk> accessed 7 May 2020.

75 B Langstaff, 'Statement of Approach - Core Participant Status' (2018) $<$ infectedbloodinquiry.org.uk/sites/default/files/documents/Statement-of-Approach-CoreParticipant-Status-1.pdf> accessed 7 May 2020. 


\section{WHAT ARE THE LEGAL MECHANISMS FOR SEEKING SOLUTIONS TO DISPARITIES IN THE DELIVERY OF CARE IN THE NHS}

the only examples of its involvement is related to hospitalised deaf patients. ${ }^{76}$ Other potential Core Participants might include Monitor (now NHS Improvement), the Care Quality Commission, local Clinical Commissioning Groups and Health and Well-Being Boards as well as relevant Trusts. The track record of these organisations as far as BEM communities being underserved is non-existent.

Monitor's role was defined in the Health and Social Care (Community Health and Standards) Act 2003 as:

4 (b) reducing inequalities between persons with respect to their ability to access those services, and

(c) reducing inequalities between persons with respect to the outcomes achieved for them by the provision of those services.

To date it has failed to publish any examples of having intervened to address inequalities in service delivery related to ethnicity. Similarly the Care Quality Commission (CQC) has failed in this area. In describing its work the CQC stated its objectives were to "help to focus providers and commissioners on the importance of their responsibilities towards equality, diversity and human rights", and to ensure that, "an organisation provides services proportionately to different groups and their needs". ${ }^{77}$ However, it is yet to publish any outcomes of work on the health care of patients from the BEM community. Health and Well-Being Boards' role is advisory representing local groups but lacking any enforceable powers. In contrast Clinical Commissioning Groups are directly responsible for the purchase of appropriate care for patients in their locality and so share responsibility with NHS Trusts for ensuring equitable access to services and treatment. The Public Sector Equality Duty identified in the Equality Act 2010 is the basis for the statement in the NHS Constitution that:

Legal duties require NHS England and each clinical commissioning group to have regard to the need to reduce inequalities in access to health services and the outcomes achieved for patients. ${ }^{78}$

\footnotetext{
76 Equality and Human Rights Commission, Section 23 Agreement between The Equality and Human Rights Commission and Tayside Health Board This Agreement (2014) <https://www.nhstaysidecdn.scot.nhs.uk/NHSTaysideWeb/idcplg?IdcService= GET_SECURE_FILE\&Rendition=web\&RevisionSelectionMethod=LatestReleased\& noSaveAs=1\&dDocName=prod_226503 $>$ (accessed 4 January 2021).

77 Care Quality Commission <cqc.org.uk/content/about-us> accessed 7 May 2020.

78 Department of Health, 'Guidance: The NHS Constitution for England' (2015) < gov.uk/ government/publications/the-nhs-constitution-for-england/the-nhs-constitution-forengland $>$ accessed 7 May 2020.
} 
Such organisations are likely to be Core Participants. Their financial weight will give them a significant advantage in presenting and defending their case compared to the charities concerned with inflammatory bowel disease. In 2016 company accounts revealed that Crohn's \& Colitis UK had assets of $£ 3$ million with an annual expenditure of $£ 1$ million $^{79}$ and charity returns for CICRA, the other self-help group, showed assets of $£ 600,000$ with an annual expenditure of $£ 300,000 .{ }^{80}$ Should a pressure group emerge from the BEM community its funding will be dwarfed in comparison to NHS related organisations. Nevertheless, it would be essential that patients are directly represented so they can help formulate the direction of any inquiry and have all the advantages of being Core Participants.

\section{Statutory Inquiries and Duties of Confidentiality}

Any organisation accused of underserving the BEM community will claim the information needed to answer questions is protected by medical confidentiality. ${ }^{81}$ However, Nicholas Lewis v Secretary of State for Health (defendant) \& Michael Redfern QC (interested party) ${ }^{82}$ found that the public interest in disclosing medical records outweighed any interest in maintaining their confidentiality. A further significant issue when assessing differences in delivery of care would be the disclosure of records related to patients from the white community, who had received good quality of care. Only through such disclosures would it be possible to demonstrate underserving of one community compared to another.

\section{Statutory Inquiries and Standard of Proof}

To date, all academic publications on delivery of substandard care to BEM communities have involved case series, cohort or community based studies. They have demonstrated general attitudes rather than drilling down to individual cases. Clearly, any public inquiry into underserving of BEM communities would need to define the standard of proof which it would accept. To some degree this will be influenced by the possible consequences of an inquiry finding that there has been discrimination. The 2005 Act provides no guidance in this area of standard of

${ }^{79}$ Crohn's and Colitis UK <beta.companieshouse.gov.uk/company/05973370/filinghistory $>$ accessed 7 May 2020.

${ }^{80}$ CICRA <cicra.org/media/1336/annual-report-2018.pdf> accessed 7 May 2020.

$81 \mathrm{~J}$ Beer, 'Evidence and Procedure' in J Beer, J Dingemans and P Lissack, Public Inquiries (OUP 2011) 193.

82 [2008] EWHC 2196 (QB). 


\section{WHAT ARE THE LEGAL MECHANISMS FOR SEEKING SOLUTIONS TO DISPARITIES IN THE DELIVERY OF CARE IN THE NHS}

proof. ${ }^{83}$ However, it needs consideration. For example, could such a finding be used as the basis for payment of compensation to individuals and families? In the Bloody Sunday Inquiry Saville L ducked the question, stating: "it seems to us that we can and should reach conclusions without being bound by rules designed for court cases, such as who has the burden of proof and the strict rules of evidence." 84 The situation may be easier in an inquiry into underserving of BEM communities as this would be a civil issue and "balance of probabilities" would be the standard.

\section{Statutory Inquiries and the Consequences of Confirmation of Underserving BEM Communities}

A statutory public inquiry can only make recommendations when required to do so by its Terms of Reference. ${ }^{85}$ However, even then there is no requirement that Parliament takes any action on them. ${ }^{86}$ From a patient's perspective a statutory public inquiry could be disappointing - an expensive and prolonged investigation with results which they already knew leading to no change. In 2002 Walshe and Higgins reviewed the impact of all forms of inquiry on the NHS and concluded that:

The consistency with which inquiries highlight similar causes suggests that their recommendations are either misdirected or not properly implemented. Certainly there are few formal mechanisms for following up the findings and recommendations of inquiries. However, many of the problems identified by inquiries are cultural and demand changes in attitudes, values, beliefs, and behaviours-which are difficult to prescribe in any set of recommendations. ${ }^{87}$

There are no indications that the situation has improved and the need for changes in attitude remains a major stumbling block to reform. In the case of inflammatory bowel disease, publication of evidence of underserving of BEM

83 J Aiken, 'Inquiry reports and the duty to be fair' in J Beer, J Dingemans and R Lissack, Public Inquiries (OUP 2011) 370.

${ }^{84}$ L Saville, 'Standard of proof ruling' (2004) para $18<$ webarchive.nationalarchives.gov. uk/20101103103956/http://www.bloody-sunday-inquiry.org/rulings/tribunal/Archive/ proof.pdf> accessed 7 May 2020.

85 s 24(1)(a) Inquiries Act 2005.

86 Beer (n 27) 25.

${ }^{87}$ K Walshe and J Higgins, 'The use and impact of inquiries in the NHS' (2002) 325 British Medical Journal 895. 
communities has achieved nothing. For example, when asked through a Freedom of Information request what had been done, University Hospitals of Leicester NHS Trust replied complacently:

There is no intent within the Trust for there to be inequitable access by the South Asian Community and other community groups to treatment with biologics. Indeed, the service considers that as the population of Leicester has a white English minority with a very large South Asian presence, it would be both difficult and unlikely for there not to be equitable access to biologic therapy. ${ }^{88}$

In 2004 Sir Ian Kennedy, who chaired the Bristol Royal Infirmary Inquiry, confirmed that once its report is delivered an inquiry "ceased to have any standing". ${ }^{89}$ As a result there was no mechanism for formal review of whether recommendations had been implemented, a suggestion, which the Executive, failed to incorporate into the Inquiries Act 2005. However, Rough ${ }^{90}$ has pointed out that the more individuals who take part in the debate which surrounds an inquiry, the more difficult it becomes for the relevant industries, in this case the NHS, to insulate themselves from scrutiny.

\section{NON-STATUTORY INQUIRIES}

The decision whether an inquiry should be statutory or non-statutory is made after advice from the Cabinet Office Propriety and Ethics Team. In recent times non-statutory inquiries are held when matters of intelligence need to be considered in camera..$^{91}$ Their relevance, therefore, to underserved BEM communities may be questioned. However, prior to the Inquiries Act 2005 they were a popular method of reviewing problems within the NHS. ${ }^{92}$ They continue to be used with a recent example being the investigation into the maternity and neonatal services at University Hospitals of Morecambe Bay NHS Foundation Trust. ${ }^{93}$ The rationale

\footnotetext{
${ }^{88}$ University Hospitals of Leicester NHS Trust, Freedom of Information Request GB/ FOI/30912.

89 I Kennedy, 'Government by inquiry' (2004) Question 654 <publications.parliament. uk/pa/cm200405/cmselect/cmpubadm/uc51-i/uc5102.htm> accessed 7 May 2020.

90 E Rough, 'Policy learning through public inquiries? The case of UK nuclear energy policy 1955 - 61' (2011) 29 Environment and Planning C: Government and Policy 24.

91 Caird (n 49) 6.

92 Walshe and Higgins (n 87) 895.

93 B Kirkup, Morecombe Bay Investigation (Stationery Office 2015) 1.
} 


\section{WHAT ARE THE LEGAL MECHANISMS FOR SEEKING SOLUTIONS TO DISPARITIES IN THE DELIVERY OF CARE IN THE NHS}

for the choice of a non-statutory inquiry is unclear, but it followed on from a failure by the CQC to identify and publish concerns about practices at the hospital. An earlier investigation by Grant Thornton had concluded:

on the evidence examined it seems that an attempt to cover-up matters concerning CQC's regulation of UHMB may have taken place. The first improper action was the instruction to delete an important, internal report, which more likely than not, did occur. ${ }^{94}$

The issues at Morecombe Bay continued and one year after publication of his report, Kirkup was unhappy with the lack of progress. ${ }^{95}$ This is not surprising as a review by National Audit found that only 45 per cent of recommendations made by inquiries were adopted by the Executive. ${ }^{96}$

Clearly, should an inquiry ever happen into underserving of the BEM community by the NHS it would need to be a statutory one with none of it in camera. Even then based on previous inquiries, on the balance of probabilities, it is unlikely to have any long-term impact on delivery of care to this community.

\section{Judicial Review and Healthcare for BEM Communities}

Public law challenges to decisions within the NHS have been uncommon and often unsuccessful. ${ }^{97}$ One reason is the successful role of private law in the field of medical negligence, especially for after-the-event issues. However, public lawyers have contended that the courts have the capacity to play a more active role in 'refining the decision-making process, and consequently reducing any sense of unfairness and ultimately recourse to litigation'. ${ }^{98}$ During the second half of the 20th century there has been a reorientation of judicial review away from the

94 Grant Thornton, 'The Care Quality Commission re: Project Ambrose' (2013) <cqc.org. uk/sites/default/files/media/documents/grant_thornton_uk_llp_morecambe_bay.pdf> accessed 13 January 2019. (This document can no longer be accessed but is referred to in many publications).

95 S Lintern, 'Kirkup: Lack of progress since Morecambe Bay inquiry risks "disaster", (2016) Health Services Journal. <https://www.hsj.co.uk/quality-and-performance/kirkuplack-of-progress-since-morecambe-bay-inquiry-risks-disaster/7002897.article> accessed 4 January 2021.

96 National Audit Office, 'Investigation into government-funded inquiries' (HC 836, 2017).

97 P Bibby, Effective Use of Judicial Review (Tolley Publishing Company 1995) 98.

98 R James and D Longley, 'Judicial Review and Tragic Choices: Ex Parte B' (1995) 367 Public Law 373; A Parkin, 'Allocating Health Care Resources in an Imperfect World' (1985) 58 Modern Law Review 867. 
mediatory issues that had been the primary focus of the debate throughout the period leading up to the 1960s, towards a new and entirely 'public' task, namely, that of enforcing public duties. ${ }^{99}$ Pressure groups, representative bodies and statutory organisations have liberal access to the courts for purposes of bringing proceedings in their own names or intervening as third parties in ongoing disputes. ${ }^{100}$ Indeed, during the last five years a number of Claimants have sought judicial review against the NHS as a whole or against delegated bodies. This is not surprising considering Laws LJ's judgment in International Transport Roth GmbH v Home Secretary where individual rights were unqualified and the decisions taken had been made by unelected officials. ${ }^{101}$ This can give rise to controversy when judicial decision-making fringes upon matters of policy; ${ }^{102}$ the courts have noted that there can be merit in constraining decision makers even in those cases where no individual has been directly affected by a decision. ${ }^{103}$

\section{JUDICIAL REVIEWS AND THE NHS}

Topics have ranged from national contracts to individual concerns about current and future delivery of care. At times, the simple threat of action has resolved the problem. For example, in early 2018 the Equality and Human Rights Commission threatened action against 13 Clinical Commissioning Groups (CCGs) because of their Continuing Care policies on the basis that they were unlawful and breached the human rights of patients. The Commission's concerns related to arbitrary caps on funding and failure to consider specific needs of individual patients. However, no action was taken as the CCGs convinced the Commission that they were revising their policies. ${ }^{104}$ In contrast, a number of pharmaceutical companies have

99 TT Arvind and L Stirton, 'The curious origins of judicial review' (2017) 133 Law Quarterly Review 91.

${ }_{100}$ AXA General Insurance Ltd v Lord Advocate [2011] UKSC 46, [2012] 1 AC 868; Re E (A Child) [2008] UKHL 66, [2009] 1 AC 536; for example, M Kirby, 'Deconstructing the law's hostility to public interest litigation' (2011) 127 Law Quarterly Review 537.

101 [2003] QB 728, 765ff.

${ }^{102}$ C Harlow, 'Public law and popular justice' (2002) 65 Modern Law Review 1.

${ }^{103} R v$ Secretary of State for Foreign and Commonwealth Affairs, exp World Development Movement Ltd [1995] 1 WLR 386, 395 (Rose LJ); $R$ v Somerset CC, ex $p$ Dixon [1998] EnvLR 111, 121 (Sedley J); G Anthony, 'Public interest and the three dimensions of judicial review' (2013) 64 Northern Ireland Legal Quarterly 125.

104 Equality and Human Rights Commission, 'NHS U-turns on discriminatory policies' (2018) <equalityhumanrights.com/en/our-work/news/nhs-u-turns-discriminatory-policies> accessed 7 May 2020. 


\section{WHAT ARE THE LEGAL MECHANISMS FOR SEEKING SOLUTIONS TO DISPARITIES IN THE DELIVERY OF CARE IN THE NHS}

sought judicial review when policies constrained use of their drugs, in particular when there was an expressed preference for the products of a rival company. In 2018 Mrs Justice Whipple dismissed such an application in Bayer Plc and Novartis Pharmaceuticals UK Ltd against Various Clinical Commissioning Groups ${ }^{105}$ for their policies on which drugs should be used to treat Age-Related Macular Degeneration. There would appear to have been no cases where judicial review has been sought in relation to delivery of care by NHS Trusts. The NHS's legal arm, NHS Resolution, reported only four cases where it acted as defendant, none of which concerned clinical care or involved NHS hospitals. ${ }^{106}$ Against this background it is important to consider whether discrimination experienced by BEM patients in the form of substandard clinical care might be dealt with through judicial review.

\section{POLICIES AND DECISION MAKING IN THE NHS}

In 1995 Bibby discussed how decisions were made within the NHS. ${ }^{107}$ Although policies were often published this was not always the case. There have been no suggestions of any written policies within certain NHS Trusts which would limit the number of South Asian patients receiving expensive biologic treatment or for any other form of discrimination against members of BEM communities. However, as Bibby suggested, there are occasions where the "existence of the policy is revealed only by analysis of the treatments actually given". ${ }^{108}$ It was by such mechanisms that the under-treatment of inflammatory bowel disease amongst South Asian patients was first identified. ${ }^{109}$ The "policy" may simply reflect the fact that some clinicians show significant racial bias, believing BEM patients are less likely to adhere to treatment and take personal responsibility for management of their disease. ${ }^{110}$ It seems likely such attitudes may play a role in the underserving of patients with inflammatory bowel as they were seen less frequently by consultants, their management being left in the hands of junior doctors. ${ }^{111}$

105 [2018] EWHC 2465 (Admin).

106 NHS Resolution (2019) <resolution.nhs.uk/pca-judgements> accessed 7 May 2020.

107 Bibby (n 97) 98.

108 Bibby (n 97) 98.

109 Farrukh and Mayberry, 'Patients with ulcerative colitis from diverse populations: the Leicester experience' (n 12); Farrukh and Mayberry, 'Ethnic variations in the provision of biologic therapy for Crohn's disease: a Freedom of Information study' (n 11).

110 NN Khosla and others, 'A comparison of clinicians' racial biases in the United States and France' (2018) 206 Social Science \& Medicine 31.

111 Farrukh and Mayberry, 'Patients with ulcerative colitis from diverse populations: the Leicester experience’ (n 12). 


\section{CRITERIA FOR A JUDICIAL REVIEW AND AGAINST WHOM WOULD IT BE SOUGHT}

\subsection{1 of Civil Procedure Rules 1998 identifies:}

the principal questions which arise when deciding whether it is appropriate to bring a claim by way of a claim for judicial review, are namely:

(1) Against which person or bodies does judicial review lie?

(2) Is the measure, action or omission challenged one that is amenable to judicial review?

(3) On what grounds does judicial review lie?

(4) Who can apply for judicial review?

Civil Procedure 54.1.2 states that such a person can seek review against "any person or body performing public duties or functions" and that a claim for judicial review includes: "54.1 (2)(a)(ii) a decision, action or failure to act in relation to the exercise of a public function".

The NHS Constitution sets out patients' rights and pledged the NHS to achieving them. The first principle was that the NHS should provide "a comprehensive service available to all". ${ }^{112}$

At the time the Lord Chancellor recognised that:

Many of the entitlements under the NHS and the duties incumbent on public authorities are legally enforceable through the mechanism of judicial review of executive action of Strategic Health Authorities and Primary Care Trusts in England. ${ }^{113}$

However, many of the rights in the Constitution are more accurately considered as summations of multiple legal obligations arising from a range of sources. One

\footnotetext{
112 Department of Health, 'Guidance: The NHS Constitution' (n 78).

113 Lord Chancellor and Secretary of State for Justice, Rights and Responsibilities: Developing Our Constitutional Framework (Ministry of Justice, The Stationery Office 2009) 44.
} 


\section{WHAT ARE THE LEGAL MECHANISMS FOR SEEKING SOLUTIONS TO DISPARITIES IN THE DELIVERY OF CARE IN THE NHS}

purpose of the Constitution is to empower patients and as such it has singularly failed. In the Third Report on its impact in 2019 it was noted that:

In 2018, 19\% of members of the public surveyed said that they had heard of the Constitution when prompted by a written description. This is a fall of $5 \%$ from the 2015 figure of $24 \%$ and an overall fall of $3 \%$ since 2009.114

In addition, the Court of Appeal has recognised in Coughlan ${ }^{115}$ that as demand will always outstrip resources the NHS may never provide a comprehensive service, but rather the Secretary of State and NHS England have a duty to promote such a service. Indeed, s2 of the Health Act 2009 only imposes a duty on NHS bodies to have regard to the NHS Constitution.

In $R$ (Tracy) v Cambridge University Hospitals NHS Trust ${ }^{116}$ Lord Dyson MR underlined that having regard to the constitution only required that commending a joint statement was sufficient. In the context of inequitable care for members of the BEM community it could, therefore, be argued that a commitment by an NHS Trust to equality as a target would be sufficient. In fact, Green $\mathrm{J}$ in $R$ (Justice for Health) Ltd $v$ Secretary of State for Health ${ }^{117}$ has described the duty to have regard to the NHS Constitution as a "target duty". However, Green J in National Aids Trust $v$ NHS England ${ }^{118}$ cited the Constitution as a "reinforcing factor" in reaching his conclusion that NHS England had misdirected itself in law. Such a use of the NHS Constitution has been made in other cases. ${ }^{119}$ Its use, therefore, in the context of purposive constructions of NHS bodies' statutory and public law duties appears to be increasing. ${ }^{120}$

In the case of underserved patients from BEM communities judicial review would be sought against those Trusts where this was happening and against Clinical Commissioning Groups who dealt with them. Clinical Commissioning

114 Department of Health and Social Care, Third Report on the Effect of the NHS Constitution (2019) 6 <assets.publishing.service.gov.uk/government/uploads/system/ uploads/attachment_data/file/770525/Statutory_report_on_NHS_Constitution_January_ for_2019.pdf $>$ accessed 8 May 2020.

115 R v North and East Devon Health Authority, ex p Coughlan [2001] QB 213, [2000] 2 WLR 622, [2000] 3 All ER 850, 51 BMLR 1, [1999] Lloyd's Rep Med 306, 97 LGR 703.

116 [2014] EWCA Civ 822.

117 [2016] EWHC 2338 (Admin).

118 [2016] EWHC 2005 (Admin).

$119 R$ (Rose) v Thanet CCG [2014] EWHC 1182 (Admin).

${ }^{120}$ H Gibbs, 'The purpose and effect of the NHS Constitution' (2017) <landmarkchambers. co.uk/resources/guide-to-the-law-of-the-nhs/> accessed 8 May 2020. 
Groups have replaced Primary Care Trusts as the bodies through which local health needs are met. Clearly, it would be inappropriate to take action directly against the NHS as a whole as many Trusts provide an appropriate level of service. ${ }^{121}$ Indeed in the case of inflammatory bowel disease six of the ten Trusts included in the study provided adequate care.

Trusts are required to collect data on ethnicity, admissions and procedures. This information is overseen by NHS Digital. ${ }^{122}$ Although Freedom of Information (FOI) requests are powerful tools for obtaining access to these data, responses are at the discretion of the local officer dealing with them and some claim that they do not collect such data as happened with Bradford. ${ }^{123}$ In addition, Bourke et al. have shown that FOI officers are more inclined to help applicants they know and consider friendly. ${ }^{124}$ It is unlikely that a patient or group concerned with underserving of the BEM community would fall into such a category.

\section{IS THE OMISSION CHALLENGED AMENABLE TO JUDICIAL REVIEW?}

English public law allows courts to control failures in the performance of public duties. s2 and s14 of the Human Rights Act 1998, which embody the right to life and not to experience discrimination, can form the basis for seeking judicial review (CPR 54.1.9). In addition $\mathrm{s} 6$ specifies that it is unlawful for a public body to act in a way incompatible with a Convention Right. The Human Rights in Healthcare Programme of the NHS recognised the impact of the Act in 2011 when it published Guidance Notes which included the statement: "Policies and the practice of care should be non-discriminatory and pay particular attention to ensuring that standards are equally high for all individuals concerned." 125 It is of concern that the program was suspended in January 2013 because of lack of funding! Some nine years later its webpage states: "The programme is on hold (January 2013) until continuation funding is found." ${ }^{26}$ There is no indication that this will happen and the program be revived.

121 Farrukh and Mayberry, 'Ethnic variations in the provision of biologic therapy for Crohn's disease: a Freedom of Information study' (n 11).

122 < digital.nhs.uk/data-and-information> accessed 7 May 2020.

123 Farrukh and Mayberry, 'Ethnic variations in the provision of biologic therapy for Crohn's disease: a Freedom of Information study' (n 11).

124 G Bourke, B Worthy and R Hazell, Making Freedom of Information requests. A guide for academic researchers (University College, London, The Constitution Unit 2012) 7. $125<$ humanrightsinhealthcare.nhs.uk/Library/az/Human_Rights_Survey_Hospital_ Patients_Guidance_Notes.pdf $>$ accessed 17 January 2019. (site not secure on 7 May 2020). $126<$.humanrightsinhealthcare.nhs.uk/About-Us/default.aspx> accessed 7 May 2020. 


\section{WHAT ARE THE LEGAL MECHANISMS FOR SEEKING SOLUTIONS TO DISPARITIES IN THE DELIVERY OF CARE IN THE NHS}

\section{ARE THERE GROUNDS FOR JUDICIAL REVIEW?}

The European Convention on Human Rights does not specifically refer to health issues. However, there have been cases which confirm that they can be considered. For example, in Turkey v Cyprus the Court reviewed access to health care but held that "no violation of Article 2 of the Convention has been established by reason of an alleged practice of denying access to medical services to Greek Cypriots and Maronites living in northern Cyprus". ${ }^{127}$ In considering how Turkey dealt with its own nationals in Șentürk \& Sentürk $v$ Turkey the Court:

reiterates that the first sentence of Article $2 \S 1$ enjoins the State not only to refrain from the intentional and unlawful taking of life, but also to take appropriate steps to safeguard the lives of those within its jurisdiction. These principles apply also to the area of public health .... It cannot be excluded that the acts and omissions of the authorities in the context of public-health policies may, in certain circumstances, engage their responsibility under the substantive limb of Article $2 .{ }^{128}$

The Court has begun to recognise the right of access to healthcare and that it should be of a certain quality. Following on from Atiman v Turkey the Court made it clear that Article 2 was not restricted to cases where there had been a death but also "where the alleged victim had not died as a result of the impugned conduct". 129 Such cases are a significant movement towards "more substantive justiciable protection" for underserved patients. ${ }^{130}$ Clearly the underserving of BEM patients would be an omission that could be brought forward for judicial review. In contrast to the care concerning Greek Cypriots and Maronites in Northern Cyprus the evidence for reduced access to healthcare is robust.

The Equality Act 2010 and the public sector equality duty (PSED) make it incumbent on the NHS to deliver equal care to all sectors of British society and this has been recognised in the advice it gives: 'Members of the public could seek judicial review of a breach of the PSED by either the Health Body or the third party.'131

\footnotetext{
127 Turkey v. Cyprus App no 25781/94 (ECtHR, 2001) para 221.

128 Mehmet Șentürk \& Bekir Șentürk v. Turkey App no 13423/09 (ECtHR, 2013).

129 Atiman v. Turkey App no 62279/09 (ECtHR, 2014).

${ }^{130}$ L Graham, 'The European Court of Human Rights and the emerging right to health' (2017) Oxford Human Rights Hub <ohrh.law.ox.ac.uk/the-european-court-of-humanrights-and-the-emerging-right-to-health> accessed 7 May 2020.

131 NHS Centre for Equality and Human Rights, The Public Sector Equality Duty and Third Party Service Providers (2012) <wales.nhs.uk/equality> accessed 7 November 2018. (No longer available).
} 


\section{WHO COULD APPLY FOR JUDICIAL REVIEW OF REDUCED ACCESS TO HEALTHCARE?}

Any person or legal person applying for judicial review of underserving of South Asian patients will need to demonstrate that they have standing. Section 31 (3) of the Senior Courts Act 1981 states that "the applicant has a sufficient interest in the matter to which the application relates".

CPR 54.1.11 recognises that if a claimant has a direct personal interest in the outcome of a claim this would be sufficient. In recent years a liberal attitude has been taken towards public interest groups representing communities or issues. Essentially the court makes its assessment through a two-stage process:

1. At the permission stage the claimant must show he has sufficient interest.

2. At the substantive hearing claimants must demonstrate they have "sufficient interest to maintain their claim for a particular remedy". (CPR 54.1.11)

Interestingly, the applicant need not personally have experienced adverse consequences of a government body decision, but simply be at 'risk of being directly affected'. ${ }^{132}$ However, with under-delivery of care to a whole community it might be argued that if the applicant had himself received poor care this was a matter for private law and so outside the scope of judicial review. In recent cases when this distinction was unclear, the trend has been to commence proceedings. ${ }^{133}$

Patients from the BEM community could base their application on a Trust's failure to fulfil a legitimate expectation. Their treatment had been simply unfair. In $R v$ Devon County Council ex $p$ Baker Brown L stated:

the claimant's right will only be found established when there is a clear and unambiguous representation upon which it was reasonable for him to rely. Then the administrator or other public body will be held bound in fairness by the representation made unless only its promise or undertaking as to how its power would be exercised is inconsistent with the statutory duties imposed upon it. ${ }^{134}$

Equality in delivery of health care falls squarely within this definition.

The discovery of discrimination in delivery of care has arisen out of academic research, but this has not excluded administrative courts giving guidance to

132 Norris v Ireland App no 10581/83 (ECtHR, 1988).

133 H Southey and others, Judicial Review: A Practical Guide (LexisNexis 2017) 214.

134 [1995] 1 All ER 73. 


\section{WHAT ARE THE LEGAL MECHANISMS FOR SEEKING SOLUTIONS TO DISPARITIES IN THE DELIVERY OF CARE IN THE NHS}

decision-makers. This was often through obiter remarks but also included granting individuals' relief. ${ }^{135}$

During the last 20 to 30 years declarations have frequently been sought by NHS Trusts to allow them to withdraw life support from patients; a declaration requiring a Trust to deliver equality of care would carry equal weight and equivalent newsworthiness. ${ }^{136}$ Although remedies granted to successful claimants are normally non-coercive declarations that public authorities are trusted to respect, where the BEM community has been shown to be underserved it is to be hoped that the court would issue a Mandatory Order and require the Trust to remedy its decision-making processes and comply with its statutory duties. Indeed, work by Platt et al. on local authorities has shown that "increases in challenge appear to be connected to improvements in quality scores, and are not simply the consequence of lawyers making work for themselves. The findings provide a quantitative basis for arguing that judicial review challenges may contribute to improvements in local government services and therefore that the effect of judicial review is neither insignificant nor wholly negative". ${ }^{137}$

\section{POTENTIAL LIMITATIONS OF JUDICIAL REVIEW IN RESPONDING TO UNDERSERVING OF THE BEM COMMUNITY}

There are several issues which limit the potential role of judicial review in this area. According to CPR 1998 r54.5 a claim form must be filed "not later than 3 months after the grounds to make the claim first arose". However, those grounds might not be recognised for a considerable time and then only through a Freedom of Information request. Such a request should be dealt within 20 working days, although the Information Commissioner can allow extensions of up to 40 days. ${ }^{138}$

\footnotetext{
135 Southey and others (n 133).

136 D Sokol, 'Aintree University Hospital NHS Foundation Trust v James: Best Interests and Futility under the Judicial Microscope' (2013) Journal of Medical Ethics <blogs.bmj. com/medical-ethics/2013/11/14/aintree-university-hospital-nhs-foundation-trust-v-jamesbest-interests-and-futility-under-the-judicial-microscope > accessed 7 May 2020.

137 L Platt, M Sunkin and K Calvo, 'Judicial review litigation as an incentive to change in local authority public services in England and Wales' (2009) ISER Working Paper Series, No 2009-05, 16 <https://www.iser.essex.ac.uk/files/iser_working_papers/2009-05.pdf> accessed 7 May 2020.

138 ICO, Time Limits for Compliance under the Freedom of Information Act (Section 10) $<$ ico.org.uk/media/for-organisations/documents/1165/time-for-compliance-foia-guidance. pdf $>$ accessed 7 May 2020.
} 
For an individual patient who has received substandard care which caused him injury the case would come under private law and compensation would need to be sought under the tort of negligence. Even though costs can be limited through a Protective Cost Order, they are likely to be a factor-limiting individuals and pressure groups taking action.

\section{Possible Actions by BEM Patients Under the Tort of Negligence}

Where an individual has received sub-standard care which has caused him or her harm then an action under the tort of negligence would be likely to succeed and should form the basis for advice given to a client/patient. However, for family and others who know BEM patients, who have received sub-standard care, it is appropriate to consider whether there might be grounds for seeking compensation under the criteria laid out for nervous shock in Alcock $v$ Chief Constable of South Yorkshire Police. ${ }^{139}$ They are that: relatives must have a relationship of love and affection with the primary victim, have direct perception of the event with unaided senses, as well as have proximity to the event or its immediate aftermath and experienced psychological injury via a single nervous shock.

The distinction between the incident at Hillsborough which was sudden, fatal and public and the chronic illness of someone with inflammatory bowel disease is clear. However, close family members, in particular, will perceive the on-going events of sub-standard care and will be in close proximity to the aftermath of such poor care. Nevertheless in Alcock the judges defined an event as a single incident which occurred at a single moment in time, so excluding potential claims by families of chronically underserved patients.

The issue as to whether there can be sufficient proximity when there is a significant gap between a breach and any consequent injury has not been adequately addressed. This would be the case where a patient experienced significant injury because of chronic under management of his disease. ${ }^{140}$ However, this view is not supported by Sion v Hampstead Health Authority ${ }^{141}$ where a father watched his son gradually deteriorate and die over 14 days due to hospital negligence. The case was struck out by Staughton LJ on the basis that "the report describes a process

\footnotetext{
139 [1991] UKHL 5.

140 J De Bono, 'Nervous shock and delayed injury' (2018) <ukhealthcarelawblog.co.uk/ rss-feed/91-nervous-shock-and-delayed-injury> accessed 7 May 2020.

141 (1994) EWCA Civ 26.
} 


\section{WHAT ARE THE LEGAL MECHANISMS FOR SEEKING SOLUTIONS TO DISPARITIES IN THE DELIVERY OF CARE IN THE NHS}

continuing for some time, from first arrival at the hospital to the appreciation of medical negligence after the inquest". ${ }^{142}$

On 13 October 2015 Andy McDonald attempted to address these issues through a Private Members Bill, which proposed that it was not a condition of the claim's success that the illness was induced by a shock, or that the claimant was close in time and space to the act or omission which causes the death, injury or imperilment of the immediate victim. ${ }^{143}$ However, the Negligence and Damages Bill failed due to ending of the Parliamentary Session.

Overall, however, the courts and judicial review are increasingly retracing the reasoning processes of public bodies so as to ensure that decisions were not made in an arbitrary or thoughtless way - something which is true of inequitable delivery of care.

\section{CONCLUSIONS AND RECOMMENDATIONS}

Recently David Williams, Professor of Public Health at Harvard, asked: "How is it possible that people with good intentions seeking to do their best can nonetheless, at an aggregate level, create a pattern of care that is so discriminatory?" $144 \mathrm{He}$ went on to say: "Our answer was implicit bias. It's also called unconscious or unthinking discrimination". ${ }^{145}$ When such attitudes are widespread in an organisation it leads to "institutional racism" as defined by MacPherson in The Stephen Lawrence Inquiry. ${ }^{146}$ Most attempts to deal with such issues have been outside of the UK, in countries such as the USA, Canada, Australia and New Zealand and largely dealt with the problems of indigenous minorities rather than migrant communities. They have largely been concerned with education and attempting to change the ethos of hospitals or public health services. It is now more than 50 years since Dr King made his plea for equality in healthcare. It was recently suggested that it may well be a further 50 years before it becomes a reality in the

\footnotetext{
42 ibid.

143 Negligence and Damages HC Bill (2015-16) <publications.parliament.uk/pa/bills/ cbill/2015-2016/0076/15076.pdf> accessed 7 May 2020.

144 Harvard Institute for Healthcare Improvement, 'Does Racism Play a Role in Health Inequities?: A Conversation Between Donald Berwick, MD, and David R. Williams, PhD, MPH' (2018) <ihi.org/Documents/OpenSchoolCourseTranscripts/David-Williams-DonBerwick-Does-Racism-Play-A-Role-In-Health-Inequities.htm> accessed 7 May 2020.

145 ibid.

146 Home Office, The Stephen Lawrence Inquiry (n 19).
} 
USA. ${ }^{147}$ The contention of this paper is that education and social programs have failed. Therefore, different approaches are needed. For individuals there can be redress through the courts for negligent care, but the issue is wider affecting whole communities and so requiring a broader approach. Such an approach would need to investigate both the causes of the problem, as well as its magnitude, and suggest methods by which the issue can be addressed.

Despite clear, published, widespread evidence that patients from BEM communities are underserved, this discrimination is recognised within the NHS by very few and there has been no co-ordinated and effective program to address the issue. The fact that the Human Rights in Healthcare Programme has been suspended for more than six years, because of lack of funding, emphasises the complacency within government and the NHS. This same culture also responds to other medical scandals with a similar complacency or, perhaps, indifference. Despite many recommendations from numerous inquiries across a number of medical areas the same issues regarding sub-standard care recur. The recent scandals at Morecombe Bay and Mid-Staffordshire Foundation Trust identified lack of staff, poor training, defective equipment and an inability to recognise that things had gone wrong as major components to the defective care provided by these Trusts. In the case of Morecombe Bay there was also evidence of a deliberate cover-up by the Care Quality Commission (CQC), which is the statutory body which should monitor performance. The situation with regard to discrimination in the delivery of care is no different. Trusts, Clinical Commissioning Groups and monitoring bodies, such as CQC and NHS Improvement, have failed to respond to published evidence of discrimination in the delivery of care. For these organisations education has had no impact and the Equality and Human Rights Commission has seldom involved itself on behalf of patients. The only approach likely to have any impact will be a legal one with individuals and institutions identified and held responsible for their actions.

The advantage of judicial review would be that individuals and institutions could be named and ordered to fulfil their statutory duties and deliver equitable care to the BEM community. However, it would deal with the issues on a case-bycase basis and only with time hopefully help change the culture across the NHS. A statutory inquiry could also require the attendance of witnesses and the disclosure of documents, but would be unable to enforce its recommendations and many would be concerned that the controlling hand of the Executive might lead to the effective suppression of evidence.

147 D Munro, 'The 50th anniversary of Dr King's healthcare quote' Forbes (25 March 2016). 


\section{WHAT ARE THE LEGAL MECHANISMS FOR SEEKING SOLUTIONS TO DISPARITIES IN THE DELIVERY OF CARE IN THE NHS}

Although a Royal Commissions lacks coercive powers, because of its nature it is prestigious. As with Statutory Inquiries it cannot institute legal action against offenders, but its inquiries can be wide ranging and it should be free of political control once active. Unlike non-statutory inquiries its report will not be "lost" from the public arena. As Saatchi has argued, it is only through the "independence and thoroughness" of a Royal Commission that there can be a "sustainable policy change in the NHS" 148 and so reverse its institutional racism. However, on an individual basis, BEM patients who have received sub-standard care need to look at more traditional routes to seek redress and that must be through actions in the tort of negligence.

148 Saatchi (n 45) 29. 